\title{
RESIDENTIAL PROPERTY MARKET IN THE FUNCTIONAL URBAN AREA OF OLSZTYN IN THE CONTEXT OF DEMOGRAPHIC CHANGES
}

\author{
Agnieszka Szczepańska, PhD \\ The Faculty of Geodesy, Geospatial and Civil Engineering \\ University of Warmia and Mazury in Olsztyn \\ e-mail:aszczep@uwm.edu.pl
}

\begin{abstract}
The development of cities is accompanied by growth of the real estate markets within the suburban zone of the municipal urban area. This is the zone functionally related to the core city, where the processes occurring in the property market result primarily from decisions taken by city dwellers concerning the choice of their place of residence. This is reflected in completed transactions, which influence demographic changes. Therefore, the property market becomes a reflection of urbanization processes taking place in this area. The conducted research concerns an analysis of the property market in the suburban zone of Olsztyn of building plots, single-family houses and residential premise segments in the context of demographic changes. The results of the research present the dynamics and directions of development of the suburban zone. The period of research covers the years of 2007-2015, and the spatial scope covers the level of communes and the surveying sections they are composed of (villages).
\end{abstract}

Key words: suburbanization, suburban zone, local property market, housing properties.

JEL Classification: $D 49, R 23, R 31$.

Citation: Szczepańska A., 2017, Residential Property Market in the Functional Urban Area of Olsztyn in the Context of Demographic Changes, Real Estate Management and Valuation, vol. 25, no. 3, pp. 30-39.

DOI: 10.1515/remav-2017-0020

\section{Suburban zone of the functional urban area and property market}

Pursuant to the Planning and Spatial Management Act of 23 March 2003 (consolidated text Dz. U. of 2016, item 778 as amended), functional areas include, among others, the functional urban area of the provincial center, which should be understood as the type of functional area including the town where the provincial government authorities or the province governor is located, and functionally related immediate surroundings making up the suburban zone. Intensive suburbanization processes occurring in this zone bring many unfavourable phenomena, including the effect of urban sprawl on previously undeveloped areas. This involves significant economic costs related to supplying utility infrastructure and communication services, and environmental effects related to the shrinking of open areas and great changes in the traditional rural landscape. Urban sprawl is the outcome of demographic pressure and certain space limitations within the administrative boundaries of the core city, as well as of the location decisions undertaken by its population, choosing the suburban zone for their place of residence. A collective decision, made of individual decisions of individual households, determines the directions of development for those areas, which is reflected in changes in the local property markets, particularly in the segment of residential properties. This submarket concerns transactions in building plots, single-family houses or residential premises. The spatial development of the town is therefore the effect of individual and collective appropriation of space (DIELEMAN and WEGENER 2004) and city dwellers buying properties situated in a specific location in rural areas 
surrounding the city as their new place of residence which thus determines the directions for migrations from the urban centre. The scale of the suburbanization phenomenon is, therefore, directly proportional to the growing consumption of building plots, single-family houses and residential premises, which translates into the development of markets of properties remaining within the zone of city influence, and results in expanding the boundaries of the "urban" real estate market (TANG and YIU 2010; HALlEUX 2009; CAPOZZA and HelSLEY 1989). Taking over residential functions by suburban areas leads to a decrease in the core city population and involves development of single-family and multi-family housing (CHMIELEWSKA 2015; RAŹNIAK and NOWOTNIK 2015; MUSIAŁ-MALAGO 2014; BICZKOWSKA 2013; SOLAREK 2013; HAASE et al. 2012; KAŁAMUCKA et al. 2012; ULAŃSKA and BOROWSKASTEFAŃSKA 2012; SZYMAŃSKA and BIEGAŃSKA 2011; CZARNECKI 2010; TAMMARU 2009; PICHLERMILANOVIC et al. 2007; NUISSL and RINK 2005; CARRIÓN-FLORES and IRWIN 2004; NECHYBA and WALSH, 2004; HARRIS and LARKHAM 2003; JAKÓBCZYK-GRYSZKIEWICZ 2002). In practice, supply and demand (as the basis for real estate market analyses) plays a significant role in the analysis of city expansion in terms of its directions and rate (Hu et al. 2012).

The aim of the paper was to illustrate the scale and developmental directions of suburbanization in the suburban zone of Olsztyn through an analysis of transactions carried out in the residential property submarket in the context of demographic change, and to indicate the areas where those phenomena are concentrated.

\section{Functional Urban Area of Olsztyn, scope of the analyses conducted and research methods}

Pursuant to the Strategy of the Functional Urban Area of Olsztyn dated 15 March 2016, the Functional Urban Area (FUA) of Olsztyn consists of the city of Olsztyn and the communes of: Barczewo, Dywity, Gietrzwałd, Jonkowo, Purda and Stawiguda directly neighbouring its administrative boundaries (Fig. 1).

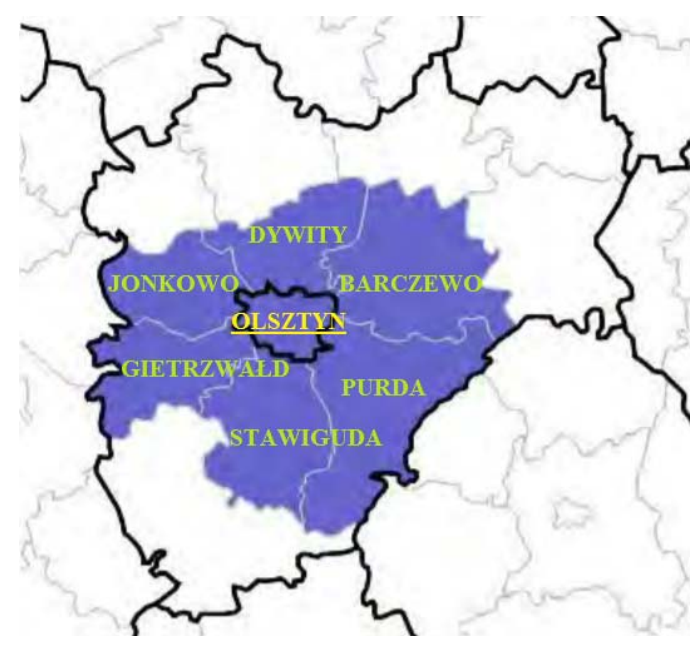

Fig. 1. Olsztyn agglomeration. Source: Strategy of social and economic development of the Warmia and Mazury Province by 2025, Olsztyn 2013.

The analyses conducted concerned the submarket of residential properties and demographic changes in two dimensions of the suburban zone: commune - as a basis for administrative division (six communes, including five rural communes: Dywity, Gietrzwałd, Jonkowo, Purda, Stawiguda and one municipal and rural commune of Barczewo, excluding the town of Barczewo) and surveying sections making up individual communes - a basis for surveying division (137 sections). The research was carried out on the basis of data obtained from the Property Price and Value Register of the District Centre for Surveying and Cartographic Documentation in Olsztyn, Local Data Bank of the Central Statistical Office (GUS) and from individual commune authorities.

The analyses were carried out in the following stages:

1. Selection of property types subject to the analysis and specifying time brackets of the analysis. Transactions chosen for the research pertained to the residential properties submarket and included, in particular: 
- transactions in building plots - where a building plot is understood in the meaning of the Planning and Spatial Management Act of 27 March 2003 (consolidated text Dz.U. of 2016 item 778 as amended) as a land property or a plot of land, the size of which (geometrical features), access to a public road and availability of technical infrastructure, satisfy requirements related to the construction of buildings set forth in separate regulations and acts of local law; the analyses were conducted both with regard to land intended in the local zoning plans for singlefamily residential housing and for land classified as arable land (or partially as forest land), where no construction works had been commenced prior to the transaction;

- transactions in single-family houses - land properties with single-family houses built on them (including shell units, purchased in the secondary and primary market),

- transactions in residential premises - residential properties (including shell units, purchased in the secondary and primary market).

The time brackets of the research covered the period between 2007 and 2015.

2. Gathering the data concerning transactions in residential properties located in the suburban zone of Olsztyn and construction of the database.

3. Making cartograms illustrating the number of transactions in individual types of properties with regard to the surveying sections (breakdown of the variable - natural Jenks distribution).

4. Selection of a variable for conducting demographic analyses and construction of the database. The variables assumed concerned registrations of residence in towns situated in the suburban zone communes and population growth in the surveying sections making up the communes.

4. Making a cartogram illustrating population growth with reference to the surveying sections (breakdown of the variable - natural Jenks distribution).

5. The analysis of spatial concentration of transactions in individual types of properties and of population growth, by calculating coefficients of concentration, with graphic illustration in the form of a Lorenz curve. In order to determine the coefficient of concentration and its graphic illustration, Concentration - Free Statistics Software Calculator was used (http://www.wessa.net/co.wasp). Coefficient of spatial concentration was calculated according to formula 1.

$$
\begin{gathered}
C=\frac{n}{n-1} G \\
G=\left(\frac{2}{n^{2} \bar{x}}\right) \sum_{i=1}^{n}\left(\left(i-\frac{n+1}{2}\right) x_{i}\right), \text { gdzie } \bar{x}=\frac{1}{n} \sum_{i=1}^{n} x_{i}
\end{gathered}
$$

where:

$C$ - concentration coefficient,

$n$ - number of observations,

G - Gini ratio,

$x$ - observation value.

\section{Property market in the suburban zone of the Olsztyn FUA}

The analyses of the property market in the building plot segment involved data concerning 5,297 transactions. The number of transactions carried out in individual communes located in the suburban zone of the Olsztyn FUA is presented in Figure 2. Out of the transactions under analysis, 1,654 concerned plots intended in the local zoning plan for residential development (MN) and 257 for residential and commercial service development (MU), which accounts for only $36 \%$ of all transactions. Therefore, it should be assumed that at the moment of concluding a transaction there were no zoning plans for the remaining $64 \%$ plots being the subject of sale and their development was made on the basis of the zoning decision.

What is clearly observed is a decrease in the number of transactions concluded after 2008, with a slight revival seen in 2015, which reflects the trends observed in the corresponding period in various segments of the property market in Poland. This is directly related to the economic crisis started in 2009, which affected the economic situation of the population and investments in the property market. In the spatial perspective, this phenomenon is presented in Figure 3.

Most transactions were concluded in the direct vicinity of Olsztyn, in communal villages and in directions of the best communication accessibility - southern and south-western direction: surveying sections situated along route No. 51 Olsztyn-Warsaw and route No. 16 Olsztyn-Ostróda. 


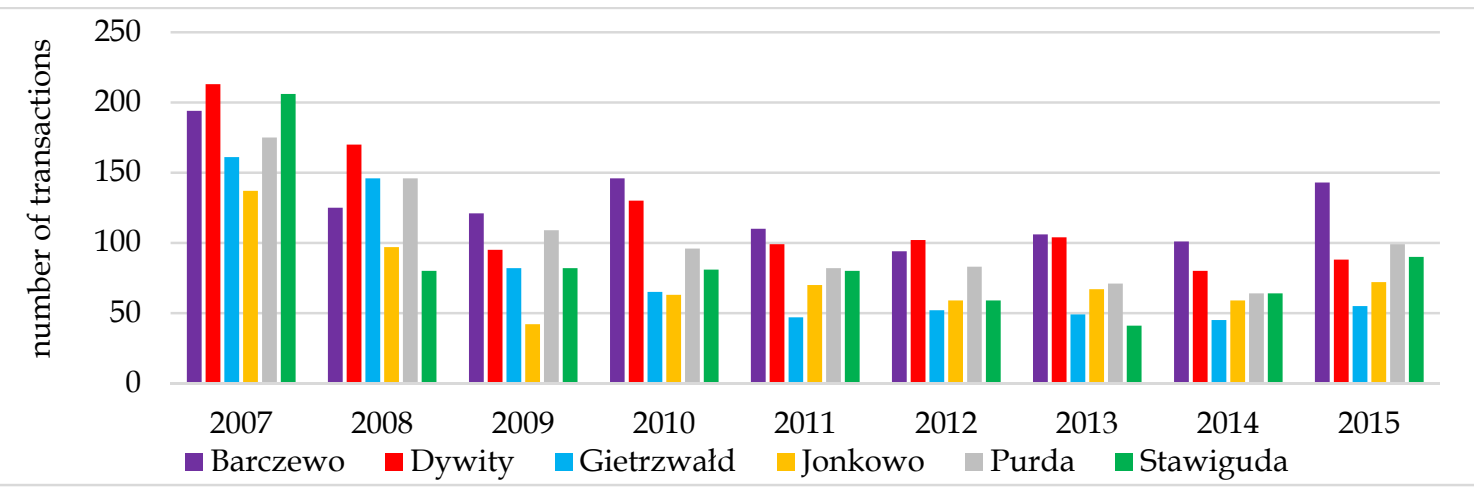

Fig. 2. Transactions in building plots in the communes of the suburban zone of the Olsztyn FUA in 2007-2015. Source: own work on the basis of the Property Price and Value Register of the District Centre for Surveying and Cartographic Documentation in Olsztyn.

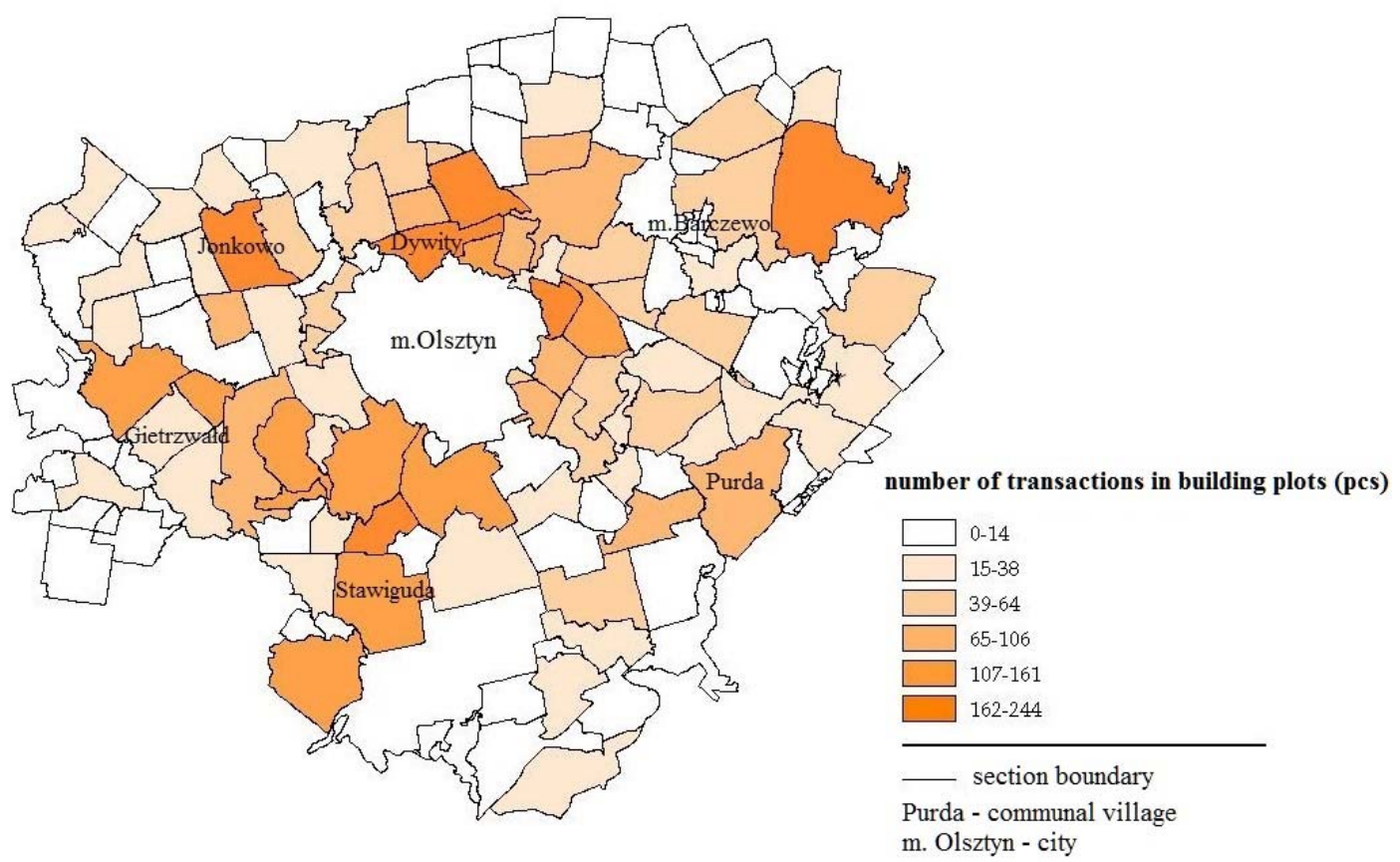

Fig. 3. Transactions in building plots in the surveying sections of the suburban zone of the Olsztyn FUA in 2007-2015. Source: own work on the basis of the Property Price and Value Register of the District Centre for Surveying and Cartographic Documentation in Olsztyn.

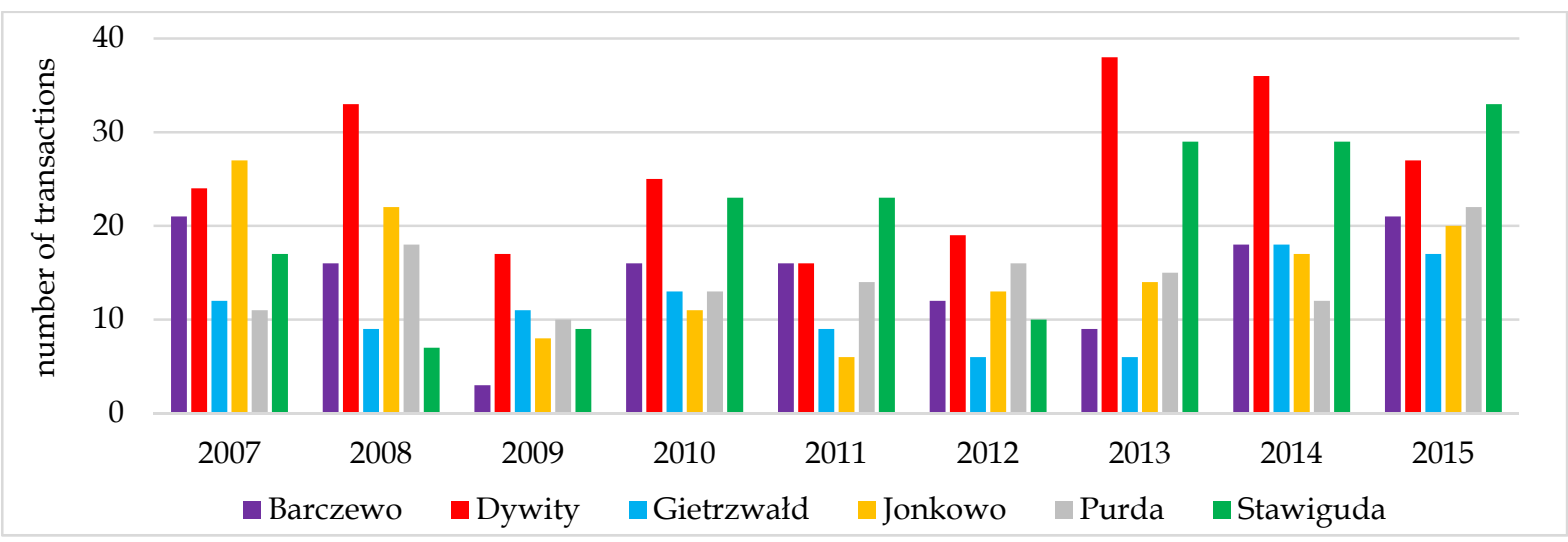

Fig. 4. Transactions in single-family houses in the communes of the suburban zone of the Olsztyn FUA in 2007-2015. Source: Own work on the basis of the Property Price and Value Register of the District Centre for Surveying and Cartographic Documentation in Olsztyn. 
The analysis was also carried out for transactions in single-family houses (917 transactions). In 135 transactions, a transaction party was a legal person; therefore it can be assumed that these were primary market transactions. The number of transactions concluded in individual communes of the suburban zone of the Olsztyn FUA is presented in Figure 4 and in a spatial perspective in Figure 5.

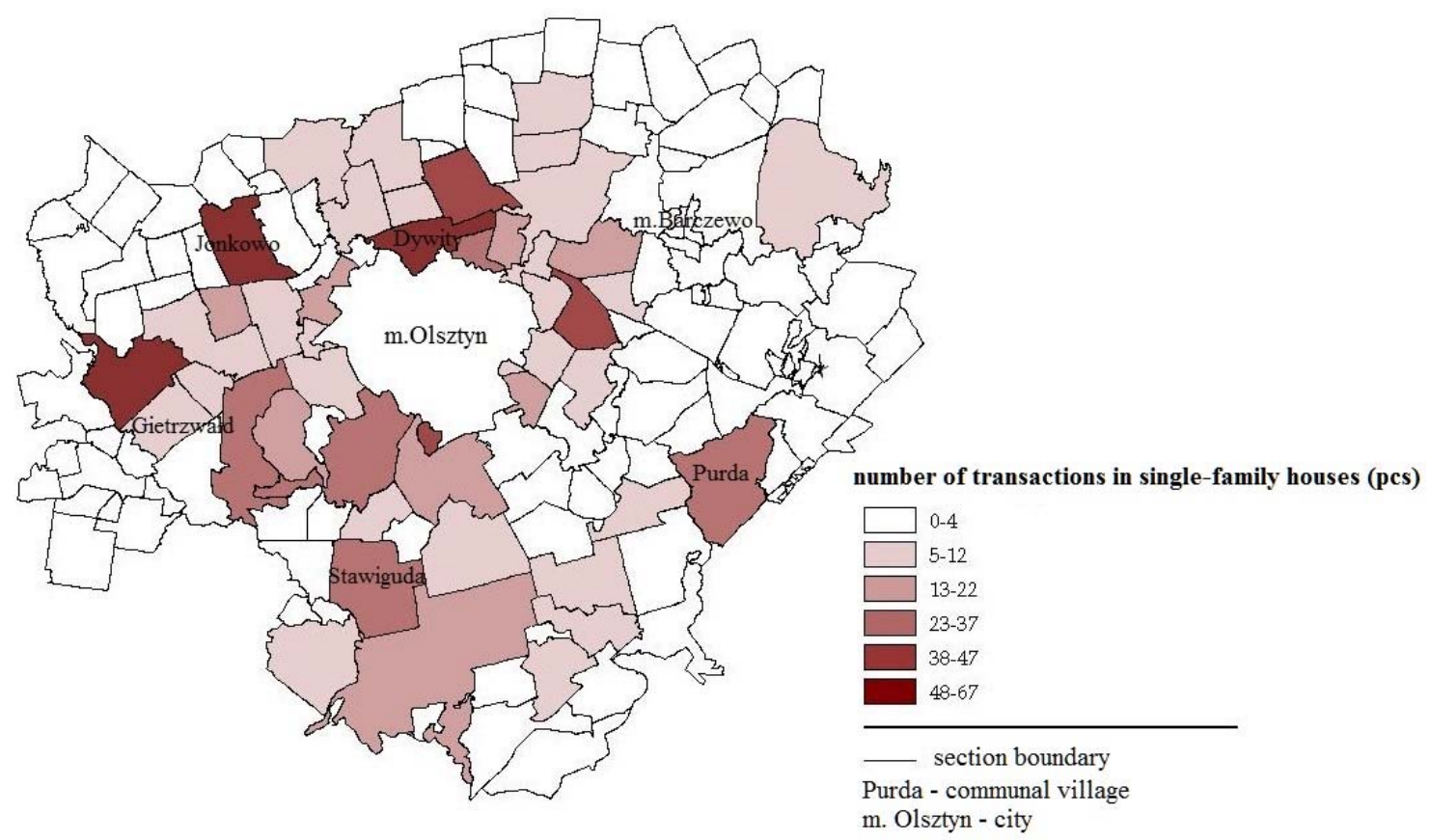

Fig. 5. Transactions in single-family houses in the surveying sections of the suburban zone of the Olsztyn FUA in 2007-2015. Source: Own work on the basis of the Property Price and Value Register of the District Centre for Surveying and Cartographic Documentation in Olsztyn.

Just like for building plots, transactions here also concentrate in the immediate vicinity of the core city, in the communal villages of Dywity, Jonkowo, Purda and Stawiguda and the surveying sections of Wójtowo, Woryty, Różnowo and Jaroty.

Transactions in residential premises were carried out essentially in three sections - in the northern direction in Dywity and in the southern direction in Bartagg and Jaroty (Fig. 7). The Bartagg and Jaroty surveying sections are currently the main direction of residential development, in particular of multifamily housing. This is an extension of the largest housing estates of Jaroty and Generałow. The majority of the effected transactions concerned the primary market (Fig. 6), as they accounted for more than $86 \%$ of all transactions.

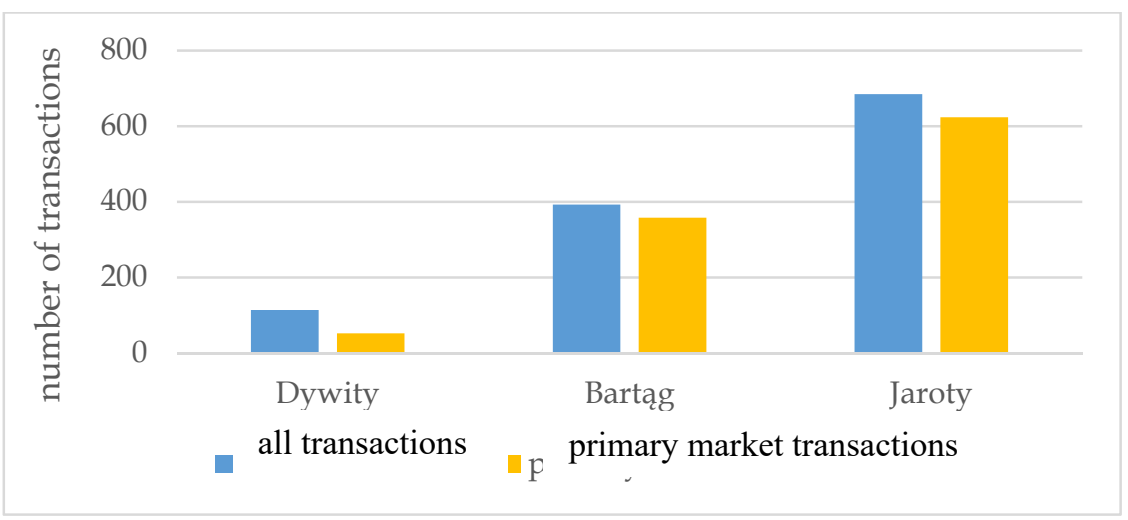

Fig. 6. Transactions in residential premises in the surveying sections of the suburban zone of the Olsztyn FUA in 2007-2015. Source: own work on the basis of the Property Price and Value Register of the District Centre for Surveying and Cartographic Documentation in Olsztyn. 


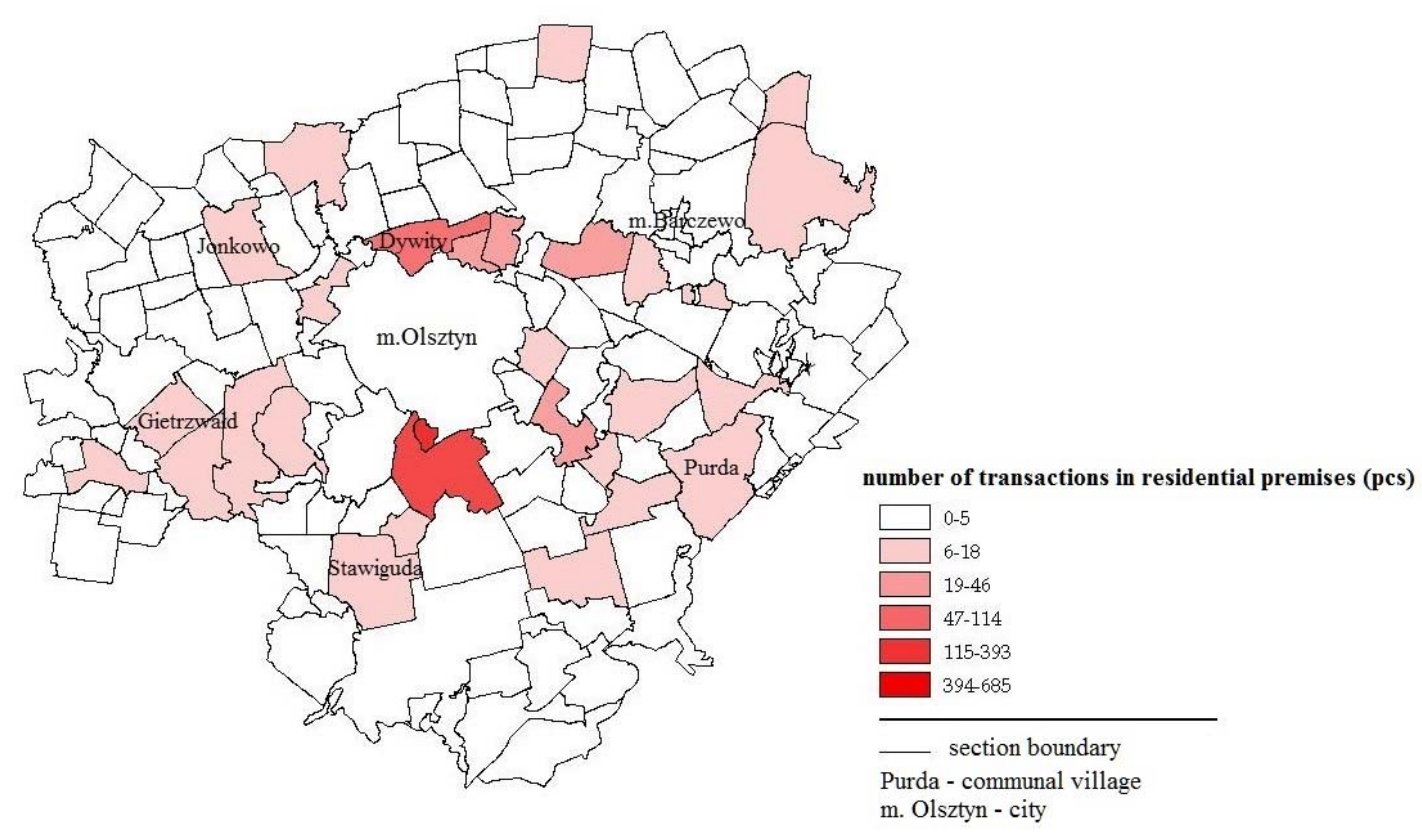

Fig. 7. Transactions in residential premises in the surveying sections of the suburban zone of the Olsztyn FUA in 2007-2015. Source: Own work on the basis of the Property Price and Value Register of the District Centre for Surveying and Cartographic Documentation in Olsztyn

The analysis of the property market is supplemented with examination of building processes, reflected in commissioned residential buildings and apartments. In 2007-2015, in total, 3,561 new residential buildings were commissioned in the suburban zone of Olsztyn (of which 3,510 accounted for private housing). For comparative purposes, the corresponding values for the area of the city of Olsztyn amount to 1,094 and 878, respectively. 4,786 apartments were commissioned in the suburban zone of the Olsztyn FUA in the period under analysis (Fig. 8), which with reference to 9,837 apartments commissioned in Olsztyn makes a significant share, of about $50 \%$. The values recorded for the commune of Stawiguda significantly differ from other communes, with local irregularities, due to multi-family housing increasing in this area.

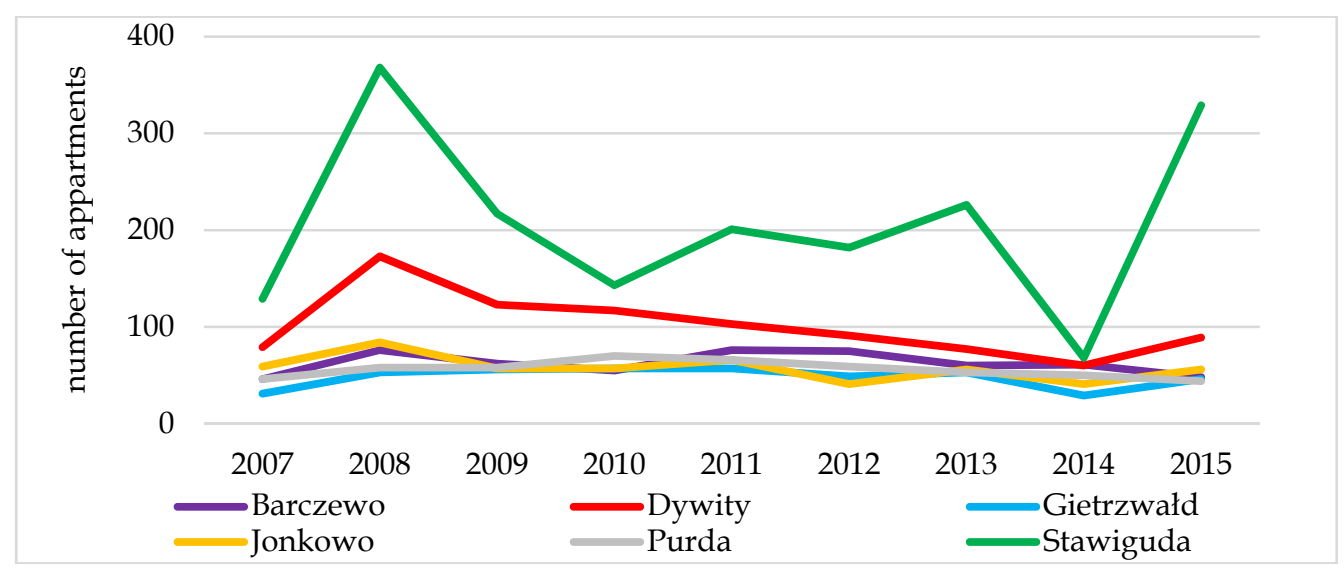

Fig. 8. Apartments commissioned in communes of the suburban zone of the Olsztyn FUA. Source: Own work on the basis of the GUS Local Data Bank.

\section{Demographic changes}

A constant population growth is observed in the communes of the suburban zone of Olsztyn. In 20072015, a relative increase in population of $20 \%$ was recorded, from 43,201 to 51,681 (by 8,480 persons), with a simultaneous decrease in Olsztyn by 2,266 persons to the level of 173,444 persons. In most surveying sections, an increase in population was observed, but there are also such, in particular at the outer edge of the suburban zone, where its decrease was recorded (Fig. 9). The largest population growths are recorded in the group of the pre-working and working age, which from the perspective of 
commune development is a very favourable phenomenon and proves the migration of families with children to suburban areas.

Registrations of residence in communes in the suburban zone of Olsztyn in 2007-2015 amounted in total to 11,344, with more than one thousand registrations in each of the years under analysis (Fig. 9). In individual communes they were subject to slight fluctuations, except 2010 in the commune of Stawiguda, where they significantly departed from average values, presumably as a result of development investments in multi-family housing. The highest inflow of municipal population to the communes of Stawiguda and Dywity is observed each year. In the spatial dimension, population growth at the level of surveying sections is presented in Figure 10.

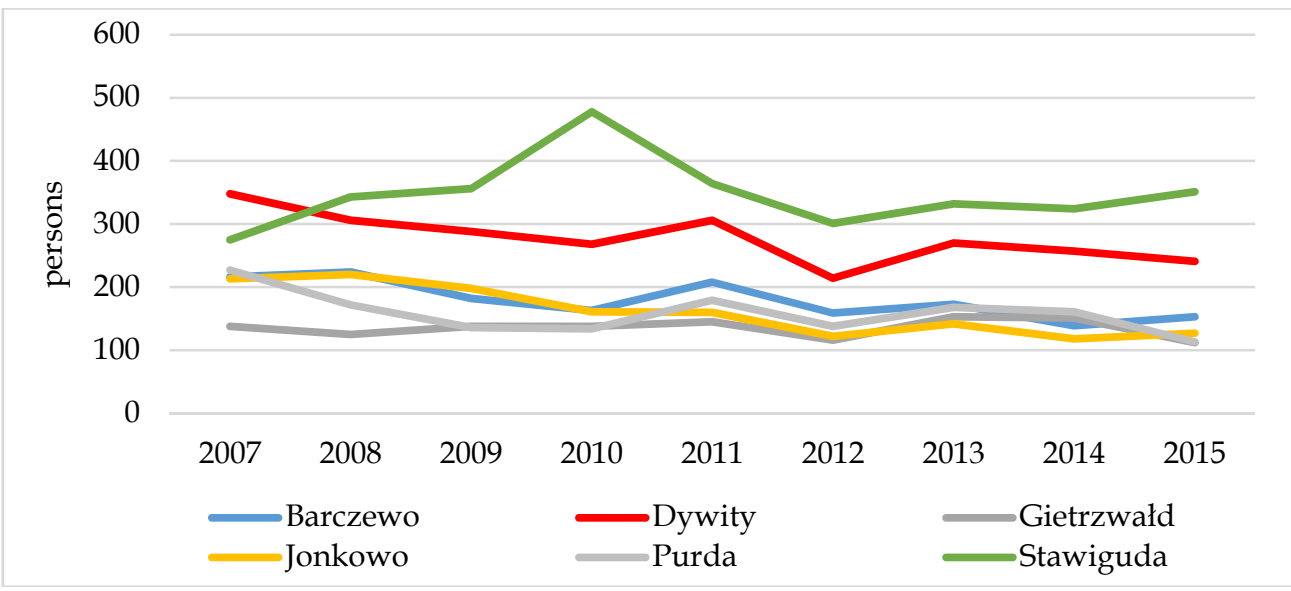

Fig. 9. Registrations of residence from towns in the communes of the suburban zone of the Olsztyn FUA in 2007-2015. Source: Own work on the basis of the GUS Local Data Bank.

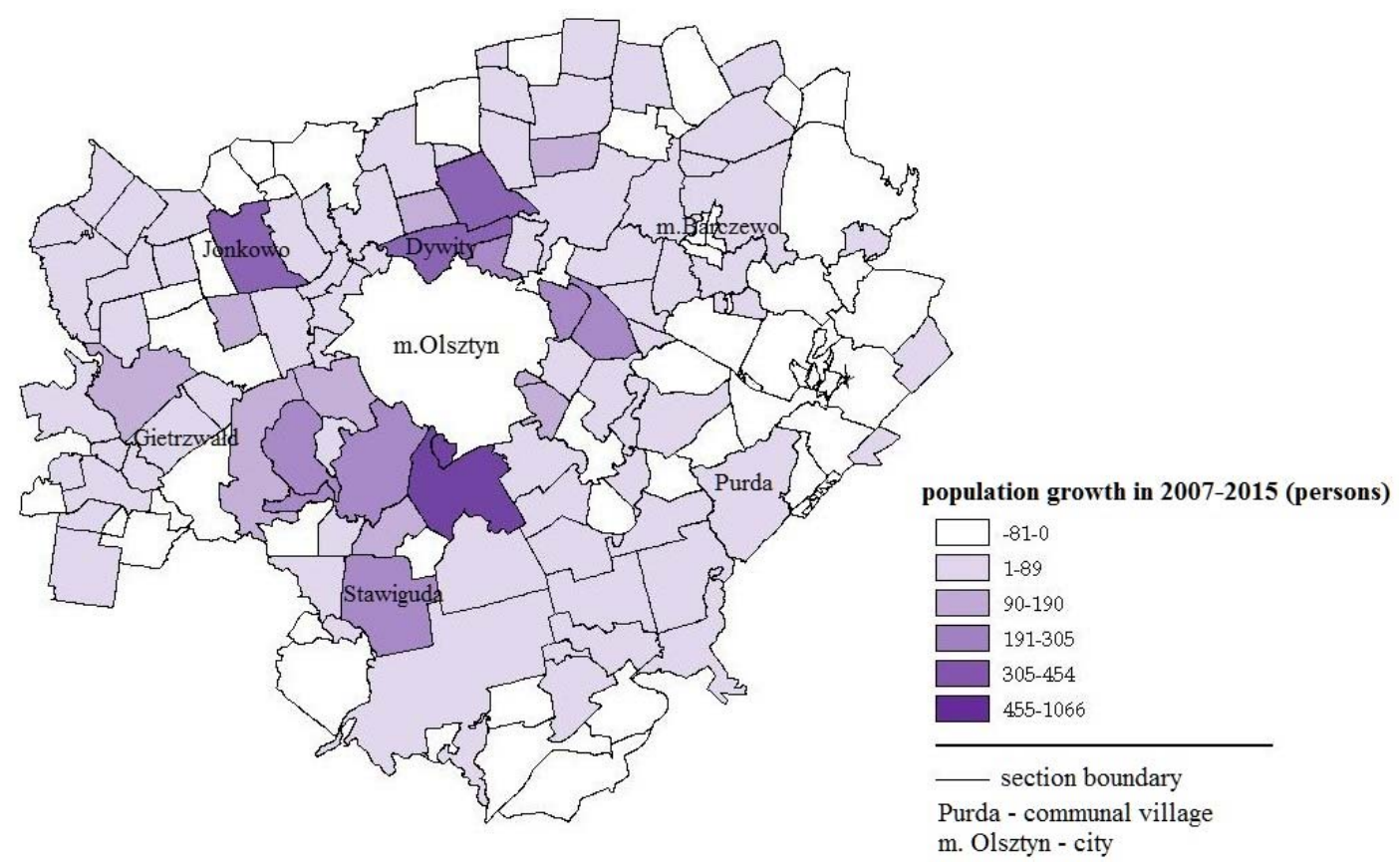

Fig. 10. Population growth in the surveying sections of the suburban zone of the Olsztyn FUA in 20072015. Source: Own work on the basis of information from commune authorities.

Population growth in individual surveying section (just like the number of concluded transactions) decreases along with the distance from the city of Olsztyn and reaches the highest values in the sections of the commune of Stawiguda and partially Dywity and in the communal village of Jonkowo.

\section{Spatial concentration}

As results from the above presented analyses of property market and demographic variables, they are of a selective nature, with spatial irregularities. To confirm this phenomenon, coefficients of spatial 
concentration were calculated at the level of surveying sections (coefficients defining spatial distribution irregularities) and graphically illustrated (Tab. 1).

Table 1

Coefficients of spatial concentration and their graphic illustration for demographic data and transactions in the local property market in the suburban zone of the Olsztyn FUA

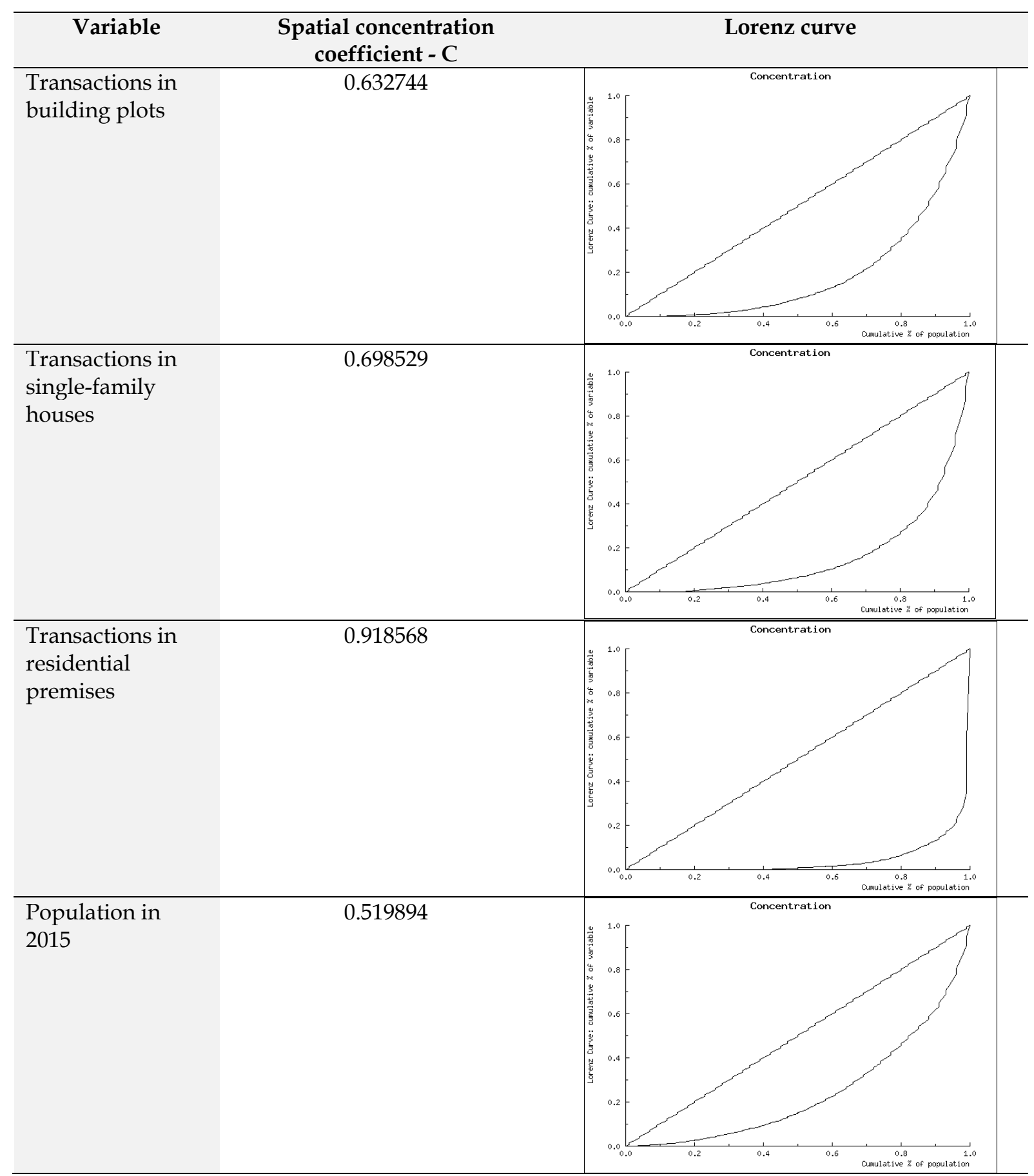

Source: Own work.

For practical reasons, it is assumed that concentration coefficient above 0.5 suggests large irregularity. Since all coefficients exceed this value, this confirms irregularities in the spatial distribution of the analysed phenomena, which is consistent with the results presented in Point 3. 


\section{Summary}

Development of contemporary suburban zones is unquestionably determined by property markets. Therefore, it can be claimed that property markets, in the segment of building plots, single-family houses and residential premises, reflect the intensity of suburbanization processes. At the same time, the intensity of transactions in the local market depends, first of all, on the size of the urban centre and distance from it, with particular consideration of the main communication routes, which affects good accessibility of a given area. A problem resulting from the urbanization processes is the lack of spatial continuity and large selectivity concerning specific spatial units. The conducted research confirms this trend. The analysed residential property market of the suburban zone of the Olsztyn Functional Urban Area shows the strongest development in the direct vicinity of the administrative boundaries or in communal villages. Although transactions in building plots and single-family houses have a broader range, the transactions in residential premises concentrate within the surveying sections directly neighbouring the city. Population growth in individual surveying sections generally corresponds to the intensity of the transactions concluded. The process of suburbanization in the suburban zone of Olsztyn is uneven, resulting in progressive concentration of transactions and in effect, of population in the area of selected sections, particularly those neighbouring the town, with good communication accessibility.

\section{Literature}

BicZKowSKa M., 2013, Przemiany demograficzne w strefie podmiejskiej Wrocławia na przykładzie gminy Siechnice (Demographic changes in the suburban zone of Wroctaw as exemplified by the commune of Siechnice), In: Wójcik M. (ed.) Regionalny wymiar przemian polskiej wsi - aspekty przestrzennoekonomiczne (Regional dimension of transformations of Polish rural areas - spatial and economic aspects). Studia obszarów Wiejskich (Studies on Rural Areas), vol. XXXIV, pp. 161-174.

BOROWSKA-STEFAŃSKA M., ULAŃSKA J., 2012, Użytkowanie ziemi i polityka przestrzenna w Łódzkim Obszarze Metropolitalnym (Land use and spatial policy in Eódź Metropolitan Area), In: BARTOSIEWICZ B., Marszat T., PielesiaK I. (eds) Spójność terytorialna Łódzkiego Obszaru Metropolitalnego (Territorial cohesion of the Łódź Metropolitan Area), Studia KPZK PAN (KPZK PAN Studies), Vol. 147, pp. 13-43.

CAPOZZA D. R., Helsley R. W., 1989, The fundamentals of land prices and urban growth, Journal of Urban Economics, Vol. 26(3), pp. 295-306.

CHMIELEWSKA B., 2015, Obszary wiejskie a presja urbanizacyjna w powiatach sasiadujacych $z$ Warszaw (Rural areas and urbanization pressure in districts neighbouring Warsaw). Mazowsze, Studia Regionalne (Mazovia, Regional Studies), Vol. 16, pp. 53-72.

CZARNeCKI A., 2010, Procesy urbanizacji na obszarach wiejskich w Polsce (Urbanization processes in rural areas in Poland), In: STANNY M., DRYGAS M. (eds), Przestrzenne, społeczno-ekonomiczne zróżnicowanie obszarów wiejskich w Polsce. Problemy i perspektywy rozwoju (Spatial, social and economic diversity of rural areas in Poland. Developmental problems and perspectives). Instytut Rozwoju Wsi i Rolnictwa Polskiej Akademii Nauk (Institute of Development of Rural Areas and Agriculture of the Polish Academy of Sciences), pp. 61-80.

DielemAn F., WeGENER M., 2004, Compact city and urban sprawl, Built Environment, Vol. 30(4), pp. 308323.

HAASE A., GROSSMANN K., SteINFÜHRER A., 2012, Transitory urbanites: New actors of residential change in Polish and Czech inner cities, Cities, Vol. 29(5), pp. 318-326.

HALLEUX J. M., 2009, The spatial structuring of interurban housing markets: application to building sites prepared for self-provided housing, Environment and Planning. A, Vol. 41(9), pp. 2143-2161.

HARRIS R., LARKHAM P.J., 2003, Suburban foundation, form and function, In: HARRIS, R., LARKHAM, P. (eds) Changing suburbs: foundation, form and function. Routledge, pp. 1-31.

HU S., CHENG Q., WANG L., XIE S., 2012, Multifractal characterization of urban residential land price in space and time, Applied Geography, Vol. 34, pp. 161-170.

JAKÓBCZYK-GRYSZKIEWICZ J., 2002., Model of development of suburban zones - the example of major Polish agglomerations, European Spatial Research and Policy, Vol. 9(1), pp. 41-52.

KAŁAMUCKA W., KAŁAMUCKI K., KAMIŃSKA A., FILIPEK M., 2012, Zmiany użytkowania terenu w Lublinie $i$ jego najbliższym sasiedztwie w ostatnim 40-leciu (Changes in land use in Lublin and its nearest vicinity in 
the last 40-year period), Barometr Regionalny. Analizy i prognozy (Region Barometer. Analyses and forecasts), vol. 4, pp. 99-110.

Musią-Malagó M., 2014, Procesy suburbanizacji obszarów podmiejskich Krakowa (Suburbanization processes of suburban areas of (racow), Zeszyty Naukowe Uniwersytetu Ekonomicznego w Krakowie (Research Papers of the Economic University in Cracow), Vol. 12 (936), pp. 63-77.

NechyBA, T. J., WALSH, R. P., 2004, Urban sprawl, The Journal of Economic Perspectives, 18(4), 177-200.

Pichler-MilanOVIC N., GUTRY-KORYCKA M., RiNK D., 2007, Sprawl in the post-socialist city: the changing economic and institutional context of central and eastern European cities, In: COUCH CH., LEONTIDOU L., Petschel-Held G. (eds) Urban Sprawl in Europe: Landscapes, land-use change and policy, Blackwell Publishing, pp. 102-135.

RAŹNIAK P., NOWOTNIK D., 2015, Zróżnicowanie procesów migracyjnych w wybranych gminach krakowskiego obszaru metropolitalnego (Diversification of migration processes in selected communities of the Cracow Metropolitan Area), Stare i Nowe Problemy Badawcze w Geografii Społeczno-Ekonomicznej (Old and new research issues in social and economic geography), vol. 3; pp. 49-66.

SOLAREK K., 2013, Struktura przestrzenna strefy podmiejskiej Warszawy. Determinanty wspótczesnych przeksztatceń (Spatial structure of the Warsaw suburban zone. Determinants of contemporary transformations), Oficyna Wydawnicza Politechniki Warszawskiej, Warszawa, Seria Architektura, (Publishing House of Warsaw University of Technology, Warsaw, Architecture series), Vol. 13.

Strategia Miejskiego Obszaru Funkcjonalnego Olsztyna z 15 marca 2016r. (The strategy of the Functional Urban Area of Olsztyn of 15 March), 2016, GEOPROFIT, Warszawa-Olsztyn 2016.

Strategia rozwoju społeczno-gospodarczego województwa Warmińsko-mazurskiego do roku 2025 (The Strategy of Social and Economic Development of the Warmia and Mazury Province by 2025), Olsztyn, 2013.

SZYMAŃSKA D., BIEGAŃSKA J., 2011, Suburban areas of large cities in Poland in the light of constant migrations, In: SOJA M., ZBOROWSKI A. (eds) Man in urban space, pp. 83-98.

TAMmARU T., LeETMAA K., SILM S., AHAS, R., 2009, Temporal and spatial dynamics of the new residential areas around Tallinn, European Planning Studies, Vol. 17(3), pp. 423-439.

TANG B. S., YIU, C. Y., 2010, Space and scale: a study of development intensity and housing price in Hong Kong, Landscape and Urban Planning, Vol. 96, pp. 172-182.

CARRIÓN-FLORES C., IRWIN E.G., 2004, Determinants of residential land-use conversion and sprawl at the rural-urban fringe, American Journal of Agricultural Economics, Vol. 86; pp. 889-904.

NUISSL H., RINK, D., 2005, The 'production' of urban sprawl in eastern Germany as a phenomenon of postsocialist transformation, Cities, Vol. 22(2), pp. 123-134. 